\title{
CHANGES IN THE ABUNDANCE OF THE LESSER SPOTTED EAGLE (AQUILA POMARINA) BREEDING POPULATION IN LITHUANIA IN 1980-2006
}

\author{
Rimgaudas TREINYS ${ }^{1}$, Eugenijus DROBELIS ${ }^{2}$, Bronius ŠABLEVIČIUS ${ }^{3}$, Vladas NARUŠEVIČIUS $^{4}$, \\ Antanas PETRAŠKA ${ }^{4}$
}

\author{
${ }^{1}$ Laboratory of Avian Ecology, Institute of Ecology of Vilnius University, Akademijos 2, LT-08412 Vilnius-21, Lithuania. \\ E-mail:rimga.t@glis.lt \\ ${ }^{2}$ Dzūkija National Park, Miškininkų 61, LT-65303 Marcinkonys, Varẻna district, Lithuania. E-mail: Eugenijus@dzukijosparkas.lt \\ ${ }^{3}$ Aukštaitija National Park, Palūšè vil., LT-30202, Ignalina district, Lithuania. E-mail: gamta@anp.lt \\ ${ }^{4}$ Lithuanian Ornithological Society, Naugarduko 47-3, LT- 03208 Vilnius, Lithuania
}

\begin{abstract}
In the mid-20 century, Lesser Spotted Eagle (Aquila pomarina) was considered to be one of the most abundant species among the birds of prey in the forests of Lithuania. The estimates of the national population changed from 300-500 to 1,500-1,800 pairs in 1994 and 2005, respectively. Changes in the population estimates did not reflect the actual population trend, but rather the level of investigation of the species in the country. In reality, the current status of the species' population is unknown due to the lack of regular, nationwide monitoring. The aim of this work was to estimate the status of the Lesser Spotted Eagle population in Lithuania. Field studies in 10 sample plots in various regions of Lithuania during the period 2003-2006 showed that the number of breeding pairs declined by $31 \%$ on average as compared to the period 1980-1998. We suggest that the population of Lesser Spotted Eagle decreased by $26 \%$ across the country during the period 1980-2006. Possible reasons of such decline are discussed in this study. Key words: Aquila pomarina, population decline, breeding habitats, Lithuania
\end{abstract}

\section{INTRODUCTION}

In the mid-20 century, Lesser Spotted Eagle (Aquila pomarina) was considered to be the second most common raptor in Lithuania after Common Buzzard $(\mathrm{Bu}-$ teo buteo) (Ivanauskas 1959). At present, Lesser Spotted Eagle still remains one of the most abundant birds of prey distributed in all regions of the country (Drobelis 2004). The estimates of the population for 1994-2001 changed from 300-500 to 900-1,200 pairs (Treinys \& Dementavičius 2004). Recent studies (2001-2005) suggest that 1,500-1,800 pairs breed in Lithuania (Treinys 2005). However, the increasing estimates of the population reflect the level of investigation of the species in the country rather than the actual population trend (Kurlavičius \& Raudonikis 2001).

Transition to the market economy and restoration of private land property during the recent 15 years have brought about dramatic changes in the national forest and agriculture sector, which might have affected the population of Lesser Spotted Eagle. No changes in the species' productivity were recorded during the study period, except those in nest-site selection and foraging habits (Treinys \& Dementavičius 2004; Treinys \& Mozgeris 2006). The lack of coordinated and nationwide monitoring did not allow to evaluate the actual population trend. The study for this reason aims to summarise the earliest and the most recent data on the trends of the Lesser Spotted Eagle population in Lithuania over the last few decades.

\section{MATERIAL AND METHODS}

Fieldwork data covered mainly two periods, 1980-1998 and 2003-2006. During the first period, data on the number of breeding pairs were obtained in 10 sample plots (Fig. 1). There are no precise records on the population trends in these territories for 1980-1998 due to irregular and fragmentary studies. Thus, the most detailed data of the earlier period were used. To estimate the current number of pairs, the mapping of the breeding territories and nesting sites of Lesser Spotted Eagle was repeatedly made in these sample plots for 2003-2006. Variations in the number of pairs in a 


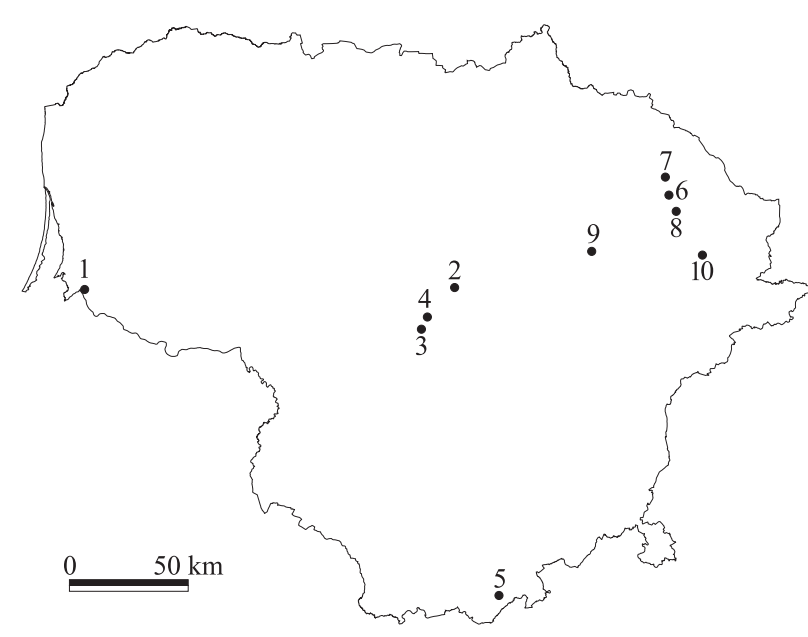

Figure 1. The distribution sample plots.

particular sample plot were evaluated based on three categories: decreased, increased or stable.

The loss of foraging and breeding habitats is known to be a crucial factor to Lesser Spotted Eagle (Meyburg et al. 2001). Larger birds of prey can expel smaller species from the territories suitable for breeding (Newton 2003). In order to discuss possible reasons for variations in the number of pairs, three factors were taken into account in each sample plot: changes in breeding and foraging habitats, and interspecific competition. The factors were grouped into relative categories based on our observations in sample plots (Table 1).

The Chi-square method was used to determine whether at least one of the three factors correlated with changes in the number of pairs in a sample plot.

\section{Results}

The number of pairs in seven sample plots declined, whereas in the other three it remained stable (the local population status in the Labūnava plot was considered as 'stable' despite the fact that the maximum number was lower). The number of breeding pairs in the investigated forests currently decreased by $27-33 \%$ ( $31 \%$ on average) as compared to the records of previous studies.

A lower number of Lesser Spotted Eagle pairs in all sample plots was significantly correlated only with the breeding of White-tailed Eagle (Haliaeetus albicilla) $(p=0.038)$, whereas no statistically significant correlation was found between the declining number of pairs, the intensity of cuttings and the status of foraging habitats.

Table 1. The evaluated factor, its category and substantiation.

\begin{tabular}{lll}
\hline Factor & Category & Substantiation \\
\hline Breeding habitats & Intensive cuttings & $\begin{array}{l}\text { Sample plots with dominating commercial forests. } \\
\text { The intensity of cuttings has increased twice since 1993 } \\
\text { annually covering }>200 \text { 000 hectares of forests } \\
\text { (DFPA 2001) }\end{array}$ \\
\cline { 2 - 3 } & Non-intensive cuttings & $\begin{array}{l}\text { Sample plots located in protected areas, where the } \\
\text { cutting is less intensive than in commercial forests }\end{array}$ \\
\cline { 2 - 3 } & Cuttings are minor & $\begin{array}{l}\text { Sample plots with minor or no clear cutting (strict } \\
\text { nature reserves and management reserves) }\end{array}$ \\
\hline Foraging habitats & Reduced & $\begin{array}{l}\text { Sample plots with overgrown or transformed } \\
\text { meadows (meadows are important foraging habitats } \\
\text { for Lesser Spotted Eagle in all distribution range, } \\
\text { Vali et al. 2004) }\end{array}$ \\
\cline { 2 - 3 } & Improved or no & $\begin{array}{l}\text { Sample plots with no visible changes in foraging } \\
\text { habitats or with an improved state of open foraging } \\
\text { areas (the increased cover of fallows and meadows) }\end{array}$ \\
\hline changes recorded & $\begin{array}{l}\text { Lesser Spotted Eagle actively responds to } \\
\text { White-tailed Eagle (Haliaeetus albicilla) (personal } \\
\text { observations). This species is known to prey on the } \\
\text { nestlings of bird of prey species (Dementavičius 2004) }\end{array}$ \\
interspecific & Breeds & Sample plots have no breeding White-tailed Eagles \\
\hline
\end{tabular}


Table 2. The sample plot, number of Lesser Spotted Eagle pairs in 1980-1998 and 2003-2006, local population status, breeding cases of White-tailed Eagle, status of nesting and foraging habitats.

\begin{tabular}{|c|c|c|c|c|c|c|}
\hline $\begin{array}{l}\text { Sample } \\
\text { plot, area }\end{array}$ & $\begin{array}{c}\text { The number } \\
\text { of Lesser } \\
\text { Spotted } \\
\text { Eagle pairs } \\
\text { in 1980-1998 }\end{array}$ & $\begin{array}{l}\text { The number } \\
\text { of Lesser } \\
\text { Spotted } \\
\text { Eagle pairs } \\
\text { in 2003-2006 }\end{array}$ & $\begin{array}{l}\text { Population } \\
\text { status }\end{array}$ & $\begin{array}{c}\text { The beginning } \\
\text { of the White- } \\
\text { tailed Eagle } \\
\text { breeding } \\
\text { attempts }\end{array}$ & $\begin{array}{l}\text { Nesting } \\
\text { habitats }\end{array}$ & $\begin{array}{c}\text { Foraging } \\
\text { habitats }\end{array}$ \\
\hline $\begin{array}{l}\text { 1. Žalgiriai, } \\
800 \text { ha }\end{array}$ & $3-4$ & 2 & Decreased & 1993 & $\begin{array}{l}\text { Cuttings are } \\
\text { minor or absent }\end{array}$ & $\begin{array}{l}\text { Remained } \\
\text { stable or } \\
\text { improved }\end{array}$ \\
\hline $\begin{array}{l}\text { 2. Lančiūnava, } \\
1,500 \text { ha }\end{array}$ & 10 & $5-6$ & Decreased & 1994 & $\begin{array}{l}\text { Intensive } \\
\text { cuttings }\end{array}$ & Reduced \\
\hline $\begin{array}{l}\text { 3. Labūnava, } \\
800 \text { ha }\end{array}$ & $5-7$ & $5-6$ & Stable & No & Intensive cuttings & $\begin{array}{l}\text { Remained } \\
\text { stable or } \\
\text { improved }\end{array}$ \\
\hline $\begin{array}{l}\text { 4. Puzaičiai, } \\
300 \text { ha }\end{array}$ & $2-3$ & $2-3$ & Stable & No & Intensive cuttings & $\begin{array}{l}\text { Remained } \\
\text { stable or } \\
\text { improved }\end{array}$ \\
\hline $\begin{array}{l}\text { 5. Čepkeliai, } \\
10,000 \text { ha }\end{array}$ & $2-3$ & 1 & Decreased & 1985 & $\begin{array}{c}\text { Cuttings are } \\
\text { minor or absent }\end{array}$ & Reduced \\
\hline $\begin{array}{l}\text { 6. Barauka, } \\
200 \text { ha }\end{array}$ & 1 & 0 & Decreased & 1995 & Intensive cuttings & $\begin{array}{r}\text { Remained } \\
\text { stable or } \\
\text { improved }\end{array}$ \\
\hline $\begin{array}{l}\text { 7. Dusetos, } \\
800 \text { ha }\end{array}$ & 1 & 0 & Decreased & 1994 & $\begin{array}{l}\text { Non-intensive } \\
\text { cuttings }\end{array}$ & $\begin{array}{r}\text { Remained } \\
\text { stable or } \\
\text { improved }\end{array}$ \\
\hline $\begin{array}{l}\text { 8. Lūžai, } \\
200 \text { ha }\end{array}$ & $3-4$ & 2 & Decreased & No & $\begin{array}{l}\text { Non-intensive } \\
\text { cuttings }\end{array}$ & $\begin{array}{c}\text { Remained } \\
\text { stable or } \\
\text { improved }\end{array}$ \\
\hline $\begin{array}{l}\text { 9. Burbiškis, } \\
200 \text { ha }\end{array}$ & $3-4$ & 4 & Stable & No & $\begin{array}{l}\text { Intensive } \\
\text { cuttings }\end{array}$ & $\begin{array}{l}\text { Remained } \\
\text { stable or } \\
\text { improved }\end{array}$ \\
\hline $\begin{array}{l}\text { 10. Ažvinčiai, } \\
5,000 \text { ha }\end{array}$ & 5 & 4 & Decreased & No & $\begin{array}{l}\text { Non-intensive } \\
\text { cuttings }\end{array}$ & $\begin{array}{c}\text { Remained } \\
\text { stable or } \\
\text { improved }\end{array}$ \\
\hline Total & $35-42$ & $25-28$ & & & & \\
\hline
\end{tabular}

\section{Discussion}

\section{Data quality}

The investigated areas were comparatively small with compact and mostly isolated forests. This enabled to do relatively accurate estimates of the number of pairs, which would be complicated to do in the area of several hundred square kilometres. Moreover, field studies also involved the period of 2005-2006 characterised by the largest number of successful breeding pairs. This facilitated the mapping of eagle individual territories and nests.
During the earlier period, mostly the method of nest mapping in winter and nest checking in summer was employed. This method excluded registration of single territorial eagles, non-breeding pairs or pairs that experienced unsuccessful breeding early in the season (only $60 \%$ of pairs breed successfully each year: Treinys \& Dementavičius 2004; Bergmanis et al. 2006). This explains why this method fails each year to detect all occupied breeding territories. For methodical consistency, only nesting pairs were counted in each of the territory for the period 2003-2006. Single territorial birds and territorial non-breeding pairs were not 
involved in this analysis. For the above-mentioned reasons, we assume that our data are not biased by natural factors or methodical differences and reflect the actual population trend. However, we can't exclude the possibility that the decline was overestimated because of the previously used method. This could be the case if during this period the proportion between breeding and non-breeding pairs had changed. Since only the number of breeding pairs was counted during both periods, the share of non-breeders increased and, consequently, this was considered a decline.

\section{Population trend}

Our study revealed a decline in the Lesser Spotted Eagle population, but the essential question how the number of Lesser Spotted Eagle pairs has changed in Lithuania still remains open. In the Lančiūnava sample plot, the number of pairs (decreasing since 1997-1998, the authors' observation) markedly decreased (Table 2). Intensive clear cuttings have been taking place in this area and the meadows have been transformed into cultivated fields since 1996-1997. White-tailed Eagle that preys on the fledglings of birds of prey (Dementavičius 2004) was observed to breed in the above site in about 1994 (D. Dementavičius, pers. comm.). The coincidence of all negative factors could account for such a sharp decline in the Lesser Spotted Eagle population in this sample plot. Consequently, we made the assumption that the Lančiūnava sample plot was not representative and excluded it from analysis. The remaining nine sample plots revealed a decline of $20-31 \%$ (26\% on average) in the number of Lesser Spotted Eagle pairs. The nine sample plots are located in different regions of Lithuania, therefore they are not impacted by specific natural conditions or landscape use peculiarities. Thus, we suggest that a similar decline (about 26\%) in the Lesser Spotted Eagle population has occurred in throughout Lithuania.

Data of our previous studies include records of different years, therefore it remains unknown when exactly the population decline started. Lesser Spotted Eagle is very attached to individual breeding territories (Vali 2003; Drobelis 2004), therefore territory abandonment is a long-lasting process (Sheller et al. 2001; U. Bergmanis, pers. comm.). Birds abandon their territory in the following succession: rare breeding pairs, non-breeding pairs and lastly single territorial birds. Thus, the species responds to natural or anthropogenic changes in habitats with a lag of several years. During the period 2001-2006, we found territories occupied by single birds and pairs that failed to produce offspring for several years. We also found territories that had been abandoned for a number of years. As a re- sult, we make the assumption that our results reflect an accomplished or continuing population decline since 1980-2006.

A population decline was also recorded in Latvia (19\%, Bergmanis et al. 2006) and Germany (Meyburg et al. 2004). Although in some countries the population remains stable, the European status of the species is evaluated as declining (for the situation in different countries see Burfield \& van Bommel 2004).

\section{Possible reasons}

The breeding density of raptors in the breeding areas are largely affected by two resources: food and nesting sites. In particular cases, the breeding density is limited by a minor resource (Newton 2003). The decline of the Lesser Spotted Eagle population in Latvia is associated with the loss of nesting sites due to intensive clear cutting in private forests, another important reason is the overgrowth of meadows after they are abandoned (Bergmanis et al. 2006). Over a 2003-2006 period, $18 \%(n=99)$ of Lesser Spotted Eagle nesting sites or their protection zones were affected by forestry activities in Lithuania. A decline in the number of pairs in each of the investigated sites is likely to be related to different factors - intensive cuttings in some places and overgrown or cultivated meadows in others. The breeding density of raptors can be limited by interspecific competition for food, predation factor (larger animals hunt smaller animals) or because smaller species avoid larger species (Newton 2003). Larger species can settle in the territories of smaller species (Hakkarainen et al. 2004) or smaller species breed at a specific distance from larger species' nests (Sergio et al. 2003). White-tailed Eagles in Lithuania have restarted breeding since 1987 and nowadays a total of 80-90 pairs breed in the country (D. Dementavičius, pers. comm.). The number of Lesser Spotted Eagle pairs have declined in all sample plots $(n=5)$ that contain breeding White-tailed Eagle. The smallest observed distance between successful nests of White-tailed and Lesser Spotted Eagles was $500 \mathrm{~m}$. In the other location, where the distance between the nests of both species was $370 \mathrm{~m}$, breeding attempts were unsuccessful for both eagles during the same year of the five-year period. Aggressive behaviour of Lesser Spotted Eagle was also often observed when White-tailed Eagle intruded into its territory. We presume that the neighbourhood of White-tailed Eagle, along with the loss of meadows and intensive forest cutting, has impact on the spatial distribution of the individual breeding territories of Lesser Spotted Eagle and diminishes the number of sites suitable for breeding. Lesser Spotted Eagle, however, has also abandoned territories with 
remaining nesting sites and apparently unchanged foraging conditions, including those vacant from larger birds of prey. The size of a migratory bird population can be affected by the factors on breeding or wintering grounds, or both (Newton 2004). Lesser Spotted Eagle is a long-distance migrant and spends half of the year outside breeding habitats (Meyburg et al. 2001). The species constantly faces the risk of being shot during migration (Meyburg et al. 2001) or perish due to unfavourable natural conditions (Meyburg et al. 2002), whereas the future population trend of longliving individuals is mostly related to adult survival rate (Balbontin et al. 2003). Lesser Spotted Eagle, as other territorial birds of prey, occupy habitats of different quality (Balbontin et al. 2003; Ferrer \& Bisson 2003), but population decline results in increased selectivity for habitats (Lõhmus 2001). This may lead to the abandonment of low-quality territories (poor foraging and breeding conditions, interspecies competition, proximity of anthropogenic elements, etc.), because predatory bird species tend to occupy habitats of higher quality as soon as they become free (Ferrer \& Bisson 2003).

\section{ACKNOWLEDGEMENTS}

Special thanks are extended to Saulius Mažiulis for providing data on the number of Lesser Spotted Eagle pairs, to Dr Darius Stončius and anonymous referees for valuable comments on the draft paper.

\section{REFERENCES}

Balbontin, J., Penteriani, V. and Ferrer, M. 2003. Variations in age of mates as an early warning signal of changes in population trends? The case of Bonelli's eagle in Andalusia. Biological Consecration 109: 417-423.

Bergmanis, U., Petrins, A., Cirulis, V., Matusiak, J. and Kuze, J. 2006. Lesser Spotted Eagle Aquila pomarina in Latvia - current status, endangerment and perspectives. Populationsökologie Greifvogel- und Eulenarten 5: 95-115.

Burfield, I. and van Bommel, F. (eds). 2004. Birds in Europe: population estimates, trends and conservation status. Cambridge, UK: BirdLife International. (BirdLife Conservation Series No. 12: 81.)

Dementavičius, D. 2004. Common Buzzard (Buteo buteo) and White-tailed Eagle (Haliaeetus albicilla): breeding parasitism or atypical feeding behaviour? Acta Zoologica Lituanica 14 (1): 76-79.

Department of Forests and Protected Areas under Minis- try of Environment, Centre of Forest Economics [DFPA] 2001. Lithuanian Forest Statistics. Lithuanian statistical yearbook of Forestry. Department of Forests and Protected Areas under Ministry of Environment, Centre of Forest Economics.

Drobelis, E. 2004. Birds of prey of Lithuanian forests. Vilnius: Spauda. [Drobelis, E. 2004. Lietuvos mišku plèšrieji paukščiai. Vilnius: Spauda.]

Ferrer, M. and Bisson, I. 2003. Age and territory-quality effects on fecundity in the Spanish Imperial Eagle (Aquila adalberti). The Auk 120 (1): 180-186.

Hakkarainen, H., Mykra, S., Kurki, S., Tornberg, R. and Jungell, S. 2004. Competitive interactions among raptors in boreal forests. Oecologia 141 (3): 420-424.

Ivanauskas, T. (ed.) 1959. Lesser Spotted Eagle. Birds of Lithuania 2: 261-264. Vilnius: Publishing House of encyclopaedias, dictionaries and scientific literature. [Ivanauskas, T. (red.) 1959. Mažasis erelis rẻksnys. Lietuvos paukščiai 2: 261-264. Vilnius: enciklopedijų, žodynu ir mokslo literatūros leidykla.]

Kurlavičius, P. and Raudonikis, L. 2001. The abundance of local breeding populations of Lithuanian birds. Ciconia 9: 92-99.

Lõhmus, A. 2001. Selection of foraging habitats by birds of prey in north-western Tartumaa. Hirundo 14: 2742 (in Estonian with English summary).

Meyburg, B.-U., Haraszthy, L., Strazds, M. and Schaffer, N. 2001. European Species Action plan for Lesser Spotted Eagle. In: N. Schaffer and U. Gallo-Orsi (eds.) European Union action plans for eight priority bird species. Luxemburg: European Commission.

Meyburg, B.-U., Matthes, J. and Meyburg, C. 2002. Satellite-tracked Lesser Spotted Eagle. British Birds 95: 372-376.

Meyburg, B.-U., Langgemach, T., Graszynski, K. and Bohner, J. 2004. The situation of the Lesser Spotted Eagle Aquila pomarina in Germany: the need for an action plan and active conservation. In: R. D. Chancellor and B.-U. Meyburg (eds) Raptors Worldwide. WWGBP/MME.

Newton, I. 2003. The Role of Natural Factors in the Limitation of Birds of Prey Numbers: A Brief Review of the Evidence. In:D. B. A. Thompson, S. M. Redpath, A. H. Fielding, M. Marquiss and C. A. Galbraith (eds) Birds of Prey in a Changing Environment. Edinburgh: The Stationery Office.

Newton, I. 2004. Population limitation in migrants. Ibis 146: 197-226.

Sergio, F., Marchesi, L. and Pedrini, P. 2003. Spatial refugia and the coexistence of diurnal raptor with its interguild owl predator. Journal of Animal Ecology 72: 232245.

Sheller, W., Franke, E., Mattes, J., Neubauer, M. and 
Scahrnweber, C. 2001. Verbraitung, Bestandentwicklung und Lebensraumsituation des Shreiadler Aquila pomarina in Mecklenburg - Vorpommern. Vogelwelt 122: 233-246.

Treinys, R. 2005. Spotted Eagles Aquila clanga, Aquila pomarina in Lithuania in 2001-2005. In: T. Mizera and B.-U. Meyburg (eds) International Meeting on Spotted Eagles (Aquila clanga, A. pomarina and A. hastata) - Research and Conservation. Proceedings of an International Symposium, Osowiec, Poland, 16-18 September 2005, pp. 43-52. Osowiec-Poznań-Berlin: Biebrza National Park.

Treinys, R. and Dementavičius, D. 2004. Productivity and diet of Lesser Spotted Eagle (Aquila pomarina) in Lithuania in 2001-2003. Acta Zoologica Lituanica 14 (2): 83-87.

Treinys, R. and Mozgeris, G. 2006. Past and present nestsite requirements of the Lesser Spotted Eagle (Aquila pomarina C. L. Brehm) and their possible conflicts with timber harvesting. Baltic forestry 12 (2): 252258.

Vali, U. 2003. Lesser Spotted Eagle and its conservation in Estonia. Hirundo Supplementum 6: 64.

Vali, U., Treinys, R. and Lohmus, A. 2004. Geographic variation in macrohabitat use and preferences of the Lesser Spotted Eagle Aquila pomarina. Ibis 146 (4): 661-671.

\section{Erelio Réksnio (Aguila pomarina) POPULIACIJOS KAITA LIETUVOJE 1980-2006}

\author{
R. Treinys, E. Drobelis, B. Šablevičius, \\ Vl. Naruševičius, A. Petraška
}

\section{SANTRAUKA}

20 amžiaus viduryje buvo manoma, kad erelis rèksnys yra viena gausiausių plěšriujų paukščių rūšis Lietuvoje. Populiacijos įvertinimas kito nuo 300-500 poru 1994, iki 1500-1800 porų 2005. Tačiau didejjantis populiacijos ivertinimas atspindejo ne realu populiacijos pokyti, bet ištirtumą šalyje. Tikrasis populiacijos statusas iki šiol buvo nežinomas, nes šalyje nebuvo vykdytas nuolatinis rūšies gausumo monitoringas. Šio darbo tikslas buvo nustatyti erelio rèksnio populiacijos statusą Lietuvoje. Lauko darbų metu 2003-2006 dešimtyje tyrimo plotu, esančių įvairiose šalies vietose, perèjo vidutiniškai $31 \%$ porų mažiau nei 1980-1998. Manome, kad visoje šalyje perinčių erelių rèksnių porų skaičius galèjo sumažèjo 26\% per 1980-2006 metų laikotarpi. Straipsnyje aptartos galimos sumažèjimo priežastys.

Received: 5 December 2006 Accepted: 28 February 2007 